\title{
Sigur Rós: Reception, borealism, and musical style
}

\begin{abstract}
Since the international breakthrough of The Sugarcubes and Björk in the late 1980s, the Anglophone discourse surrounding Icelandic popular music has proven to be the latest instance of a long history of representation in which the North Atlantic island is imagined as an icy periphery on the edge of European civilization. This mode of representation is especially prominent in the discourse surrounding post-rock band Sigur Rós. This article offers a critical reading of the band's reception in the Anglo-American music press during the period of their breakthrough in the UK and USA. Interpretative strategies among listeners and critics are scrutinised using the concept of borealism (Kristinn Schram) in order to examine attitudes towards the Nordic regions evident in the portrayals of Sigur Rós. Reception issues then form the basis for a musical analysis of a seminal track in the band's history, aiming to demonstrate how specific details in Sigur Rós' style relate to its reception and the discourse surrounding it. The article finds that much of the metaphorical language present in the band's reception can be linked to techniques of musical spatiality, the unusual sound of the bowed electric guitar, and non-normative uses of voice and language.
\end{abstract}

\section{Keywords}

Sigur Rós; Iceland; Borealism; Reception; Exoticism

\section{Author}

Tore Størvold

Department of Musicology, University of Oslo

Postboks 1017 Blindern, 0315 Oslo

Email: tore.storvold@imv.uio.no

Telephone: (+47) 41641789 
Icelandic lore tells of the Hidden People who live in the crags and lava of jagged mountains. [...] How can a modern people find faith in such fantasy? A heavy cloud of Norse mythology and a breathtaking raw landscape explains much of it. The indigenous music of Sigur Rós can only perpetuate such a religion. (DiCrescenzo 1999)

When Sigur Rós suddenly catapulted into the collective attention of the global music media at the turn of the century, quotes such as the one above were a common response. As The Sugarcubes and Björk had experienced before them, Sigur Rós would quickly find how listeners and critics mobilized the readily available mythscape surrounding Iceland when describing their music: Norse mythology, arctic landscapes, and the (often misconstrued) folk beliefs of Icelanders became props deftly employed in portraying the band as an exotic anomaly on the current indie music scene.

The present article offers a critical reading of the band's reception in the AngloAmerican music press. The study limits itself to the first years of Sigur Rós's international career and their reception in UK and US music journalism. This period forms a defining moment in the band's reception history characterized by a mode of representation that has had lasting impact on the position of Icelandic popular music in the global imagination. The popular and critical discourses surrounding Sigur Rós relate musical style to stereotypical images of nationality and geography: perpetuating an exoticised construction of an imagined Iceland.

This article views the Anglophone reception of Sigur Rós from the perspective of 'borealism' - the history of exotic imaginations of the North (Schram 2011; Bohlman 2017). In the reception of Sigur Rós, borealism is closely entwined with notions of musical style, which necessitates musicological unpacking. As such, my reading of the band's reception forms the backdrop for an analysis of their breakthrough track 'Svefn-g-englar' (1999). The music analysis aims to shed light upon certain stylistic details that are emphasised in the reception discourse surrounding the band. Even though the reception of Sigur Rós is decidedly problematic in its exoticist, myth-building tendencies, this article finds that much of the metaphorical language in use can be linked to the presence of specific musical details. These include the idiosyncratic use of voice and language, the uncanny noise of the bowed electric guitar, and techniques of musical spatiality. ${ }^{1}$

\footnotetext{
${ }^{1}$ The term 'space' has a tradition of use within popular music studies to designate the localities within which musical processes take place. In the context of the analyses in this article, however, the term 'musical space' refers to composed virtual spaces, i.e. technical means of achieving aesthetic senses of space on the part of the listener. Space in this context has been conceptualised in different ways as the 'sound box' (Moore 2012) and as
} 


\section{An All Right Start}

Sigur Rós has been active as a band in Reykjavík since the mid 1990s. ${ }^{2}$ They were unreleased outside of Iceland until the turn of the century, with the British independent label Fat Cat releasing their second album Ágcetis Byrjun ('An All Right Start') in 2000. Since then, the snowball has been steady rolling, with endless tours around the world and an additional five studio albums, the latest being Kveikur (2013). Sigur Rós has been a highly successful band in the world of indie music for the last decade, having received two Grammy nominations and an RIAA platinum certification for their music documentary film Heima (2007), in addition to Ágcetis Byrjun being declared the eighth best album of the decade by the influential music magazine Pitchfork (Pitchfork 2009).

It all began when Jón Pór Birgisson (b. 1975), also known as Jónsi, befriended bassist Georg Holm and drummer Águst Ovar Gunnarsson while they were studying at the Iðnskólinn Technical College in Reykjavík in 1993. The first recording by the band was the song 'Fljúgðu' ('Fly'), which appeared on the compilation album Smekkleysa i hálfa öld ('Half a Century of Bad Taste') which Smekkleysa, or 'Bad Taste' Records, released to celebrate the $50^{\text {th }}$ anniversary of the independent Republic of Iceland in $1994 .{ }^{3}$ Smekkleysa urged the band to record more material, which eventually became the band's debut album Von ('Hope'), not released until 1997, after the addition of keyboardist Kjartan Sveinsson.

Von sold a modest 317 copies in its first year and did not bring the band any significant attention outside of dedicated music circles (Hjálmarsson 2013, 166). Two years later, however, with the release of Ágcetis Byrjun, the band immediately ascended to the role of domestic heroes. At the Icelandic Music Awards in 2000, Sigur Rós won in six categories, and the album stayed on the Icelandic Top 20 sales list for two consecutive years, at which point it was too old to be on the list, according to the rules (ibid., 169). The band quickly gained international attention, playing their first concert outside of Iceland in London in January 2000 , followed by a year spent almost continually on the road.

\footnotetext{
'aural landscape' (Emmerson 1999). I adhere to the definition offered by Ragnhild Brøvig-Hanssen and Anne Danielsen: 'Musical spatiality refers both to the sonic locations of the sounds within space and to the sonic design of the space itself' $(2016,21)$.

2 The name of the band can be literally translated as 'Victory Rose'. However, the band name references Jónsi's younger sister, Sigurrós, who was born around the time the band was formed.

${ }^{3}$ Smekkleysa was founded by Björk and other members of The Sugarcubes in 1986. What started out as an anarcho-punk operation releasing everything from hand-printed poetry leaflets to politically charged postcards, grew into the most important independent record label in the Icelandic capital throughout the 1990s and 2000s.
} 
Ágcetis Byrjun launched the unique musical idiolect of the band: Jónsi's falsetto voice soaring high above the reverberant noise of the bowed electric guitar, repetitive bass lines, and an acoustic string section. ${ }^{4}$ Sigur Rós songs are expansive compositions that build momentum in slow tempos towards a dynamic climax. As the music of Sigur Rós travelled across the North Atlantic, the Anglophone reception tended to construct a causal relationship between the band's musical style and their place of origin.

\section{Borealism}

As Icelandic popular music has reached worldwide recognition in the last two decades, it is evident how the reception of this music in international media contributes to a larger (and, much older) discourse of an exoticised Iceland constructed by outsiders (Ísleifsson and Chartier 2011; Karen Oslund 2011). Writings in English about Icelandic music began to flourish in the late 1980s and early 1990s as a response to the international success of The Sugarcubes and Björk. One of the first rock critics to write extensively on Icelandic music was David Fricke who, in an article published in Rolling Stone magazine in 1988, set the tone for all subsequent reviews of Icelandic music when he framed it in terms of natural phenomena and the geological features of the island:

In short, it's hard to believe anything with a beat could grow in a landscape as otherworldly and physically inhospitable as that of Iceland. Mother Nature, in all her harshest majesty, is the headline act here. She is not easily upstaged. Nevertheless, in a small rehearsal space on a snowy, windblown side street in central Reykjavik, a local band called the Sugarcubes is busy proving that rock \& roll is not only alive and well here but mutating into shapes as odd and wondrous as the geologist's paradise outside. (Fricke 1988)

Here, Fricke not only supposes a direct link between musical style and the geology of the Icelandic landscape, he also makes reference to the supposed cultural otherness of an island described as 'otherworldly'. In the years following Fricke's notable writings, it has been rare to find a review of Icelandic music that does not make reference to natural phenomena such as geysers, glaciers, and volcanoes, or to popular images of the Viking age and Norse pagan

\footnotetext{
${ }^{4}$ I use the term idiolect as theorised by Allan Moore, who sees idiolect as subsidiary to style: 'Idiolect refers to the individual stylistic fingerprints (perhaps the tone of the voice, perhaps the way the kit and bass interlock, perhaps the particular guitar tone) of a performer or group of performers' $(2012,166)$.
} 
beliefs. Ethnomusicologist Kimberly Cannady sums up the situation: 'listeners from outside the region have tended to approach popular Icelandic music as an anomaly as mysterious as Iceland itself' $(2014,58)$.

The way we talk and write about music is shaped by power relations with long histories. Cannady suggests that the discursive construction of Iceland as inherently set apart from modern Europe bears witness to the 'lingering colonial inheritances' in the North Atlantic region (2014). Cannady builds a vital bridge that allows us to set studies of pop music reception into conversation with postcolonialism (2017). This perspective is important to keep in mind as we face the recent surge of pop-culture images of the 'fantasy north' - Disney's Frozen (2013) and the HBO TV-series Vikings (2013-) are just two examples - that represent the Nordic region as a magical realm on the edges of European civilization. This mode of exotic representation of the North is what Kristinn Schram terms 'borealism' (2011). ${ }^{5}$

Borealism is articulated in cultural images of the North. These images are 'created in an empirically hazy mental landscape where historical facts, rhetoric, legends and intentional or unintentional misunderstandings are mixed in a seemingly chaotic way' (Peter Stadius 2001, 5). The history of borealistic images of Iceland can be traced back to the fourth century, B.C. voyages of the ancient Greek geographer Pytheas, who named the island 'Ultima Thule' (literally 'furthest island') (John Gillis 2004, 21). ${ }^{6}$ Greek legends influenced the iconographic geographies of medieval Europe that depict Iceland as a half-mythical island in the liminal space of North. The most tenacious images of Iceland were forged in the age of European romanticism in the nineteenth century, when artists and poets such as William Morris and W.G. Collingwood made pilgrimages to Iceland and found a country that perfectly fit a certain romantic notion of the unspoiled, animistic, and authentic (Oslund 2011). Iceland became known as the country of natural extremes and contrasts, as the land of fire and ice, an iconic image that continues to drive an unsustainable nature-based tourism on the island (Karlsdóttir 2013). The half-mythical, half actual Ultima Thule still lingers on in the Anglophone reception of Icelandic popular music. Consider David Fricke's article mentioned above, which begins with the sentence 'Welcome to Iceland - Pop Music's Final Frontier!'. This mode of representation is especially prominent in the Anglophone reception of Sigur Rós, the most successful band to emerge from Reykjavík's independent music scene.

\footnotetext{
${ }^{5}$ Schram's work on borealism is based on postcolonial discussions of attitudes towards the Other. Edward Said's classic Orientalism (1978) is important in this respect, as is Michel Foucault's theories of discourse and power. ${ }^{6}$ There is some controversy regarding Pytheas' exact route and the location of the island which he named Thule. For a discussion of the classical sources, see Whitaker (1982).
} 


\section{'My Bloody Valentine played by mountain elves'}

Journalistic features and reviews of Sigur Rós generally fall within a paradigm of rock criticism known as 'folkloric authenticity' (Hans Weisethaunet and Ulf Lindberg 2010), whereby the music is taken to express the sentiment of a group or community of people. In the case of Sigur Rós, this mode of rock criticism converges with the legacy of borealism: The authenticity of the music is related to its origins in a mythical land of fire and ice. Beginning with the reviews in British music magazines following the international release of Ágatis Byrjun in 2000, a certain vocabulary and ways of writing about the band were quickly established. This is a discourse built up through tropes of the exotic and unfamiliar. The first mention of the group in an English-language music magazine holds nothing back, describing them as 'A band blessed with poignant, almost-feminine vocals and hugely moving sonic waves bearing a warmth to melt snowcaps, and, when the mood takes them, a momentous frostiness to build them back up again' (Crysell 2000). Metaphors of landscape and natural phenomena such as glaciers and volcanoes are prevalent, as are adjectives such as 'angelic', 'mournful' and 'meditative'. Consider Robert Sandall's 2005 feature for The Sunday Times titled 'The Icemen Cometh', or Rob Young's notable piece for The Wire which describes the band as being 'desolation angels' and 'hardy children of nature'. Such descriptions perpetuate established mythologies of Icelanders as a people especially attuned to nature.

Philip Bohlman credits Johan Gottfried Herder with creating, in the late eighteenth century, a lyrical language of the North that focuses on 'the sights and sounds of nature, increasingly the force that localizes the boreal' $(2017,41)$. This mode of boreal lyricism is ever-present in stylistic descriptions of Sigur Rós. Consider metaphors such as 'a glacier slowly making its way across a snow-capped continent' (Klein 2002) or 'the tinkling and cracking of ice floes drifting across the water' (Harrington 2001). These quotes are taken from critics writing for major American newspapers right around the time that Sigur Rós started to gain attention in the USA. Such descriptions attach extra-musical programs for the listener, which colours and guides the listening experience in the direction of certain interpretative strategies, in this case those of geography, natural phenomena, and nationality. ${ }^{7}$

\section{$<$ Insert table 1 here $>$}


One particularly noteworthy example of borealism in the Sigur Rós reception is a feature article published in the British music magazine The Word in 2006, 'Mordor on the Dancefloor', with the subtitle 'Having circled the globe, Sigur Rós bring their Norse mythology home to the Tolkien landscape of their native Iceland' (Mclean 2006, 65). Although Tolkien - a scholar of Old Norse philology- did use elements of the ancient epic literature of Iceland in his works, the reference in this context serves no other purpose than to construct an image of Iceland as a fantasy realm on par with Tolkien's own Middle Earth. Later in the same text, the music of Sigur Rós is described as 'My Bloody Valentine played by mountain elves' (66). This is a particularly violent act of representation that not only exoticises but also dehumanises the band members. ${ }^{8}$

\section{$<$ Insert figure 1 here $>$}

As the above example illustrates, many commentators view the stylistic originality of Sigur Rós' music as some kind of 'supporting evidence' in efforts to construct fantastical images of Iceland. The link to Tolkien is reminiscent of the Anglophone discourse accompanying the revival of 1970s Swedish prog rock, in which the music is characterised as 'gnome rock' and 'hobbit rock' (Hyltén, Cavallius and Kajser 2017). These somewhat ridiculous descriptions become more intelligible if we consider Bohlman's argument that the 'boreal' in European music history includes a process by which 'the teleological gap between myth and history is closed, and from this common terrain the boreal emerges as, at once, ancient and modern' $(2017,40)$.

The language of borealism fixes Sigur Rós in place as an above-all Icelandic band, denying them the chance to be discussed on equal footing, with equal words, to that of AngloAmerican music. However, the power-dynamic involved here is complex and evolving: the narratives that affirm the peripheral position of Iceland also ascribe cultural capital to the 'cool and authentic Nordic', which can greatly benefit artists within certain genres. Musicians deal with these narratives in different ways: some try their best to oppose them by crafting alternative, cosmopolitan ideas of Nordicness, while others play into the discourse of borealism in strategic ways with varying intentions and varying degrees of sincerity.

\footnotetext{
${ }^{8}$ On the characterization of Sigur Rós as 'mountain elves', consider Edward Said's point that the Other is often imagined as belonging to the margins of what is natural or even beyond it $(1979,54)$.
} 
Listeners and critics rarely construct meaningful interpretations of the work of an artist or a band simply by listening to the recordings alone. Album covers, music videos, and promotional photographs all play their part in giving shape to different 'hearings' of Sigur Rós. As the band gained attention outside of Iceland at the turn of the century, the music was accompanied by striking album covers, such as the surrealist angel fetus of Ágcetis Byrjun and the white minimalism of (), images that might steer interpretative efforts towards the mysterious and unearthly. Similarly, the band's award-winning music videos have at times featured cinematic shots of Icelandic landscapes in narratives that connect windswept cliffs and moss-covered rocks to themes of childhood wonder and magical experiences (as in the videos for 'Svefn-g-englar', 'Glósóli', and 'Sæglópur').

The band members themselves have always been reluctant to discuss the musical meanings of their work in interviews, preferring to let the music 'speak for itself'. They have never issued official English translations of the lyrics, and in the first years of their international career did hardly any promotional or publicizing work. Being signed to an independent label, the band retained control of their output. In the promotional material and press releases of the 2000-2005 period, the band's management and PR team mostly avoided descriptions that play into Borealist narratives. In the international press releases accompanying their first singles and the albums Ágcetis Byrjun and (), there are no mentions of the familiar tropes of nature, isolation, and remoteness. ${ }^{9}$

At times, the band has enjoyed a teasing, tongue-in-cheek relationship with international journalists. This includes 'baiting' the journalists by exploiting their stereotypical views of Icelanders, for instance by putting out the humorous story of bassist Georg Holm capturing trout with his teeth (Petrusich 2008). Once back home, the naivety of foreign reporters was a recurring subject discussed with Icelandic journalists. In an interview with music sociologist Árnar Eggert Thoroddsen in the newspaper Morgunblaðið, they discuss the awkward situations that arise when foreign reporters realize the band is not living up to their pre-conceived notions (Thoroddsen 2005).

\footnotetext{
${ }^{9}$ During the first years of the band's career, Smekkleysa and Fat Cat handled the promotion of Sigur Rós' music in Iceland and abroad, respectively. Fat Cat's press releases for Sigur Rós can be viewed online: https://www.fatcat-usa.com/press/artist/sigur-ros (accessed 18 June 2018). The press material becomes more difficult to trace further on in the band's career. For the release of their third album Takk... (2005), the band signed with EMI Records, and were consequently bumped up into a massive world-wide distribution and promotion machine. The dynamics between representation and agency in relation to borealism becomes more complex after the production of the band's music documentary film Heima (2007), which is discussed elsewhere (Dibben 2009; Fletcher 2011; Richardson 2012; Hall 2014).
} 


\section{Sleep Angels: Genre, Style, and Form in 'Svefn-g-englar'}

Even though the reception of Sigur Rós in the English-language press is shaped by borealism, it takes as its starting point the distinctive musical style of the band. Indeed, another trope in the reception is that the band sounds like no other, or is simply 'indescribable'. This critical trope of music which 'goes beyond language/description' has been identified by Hodgkinson (2004) as fundamental to the shared discourse in music magazines and fanzines constructing the genre of post-rock. The first years of the 2000s witnessed the discursive formation of Sigur Rós' central position within the canon of this newly minted subgenre.

As genre terminology, post-rock was coined by Simon Reynolds in a series of articles in the early 1990s for publications like Melody Maker and The Wire, where Reynolds used the term in relation to bands that employed 'rock instrumentation for non-rock purposes' (2007, 186). Reynolds originally applied the term to a series of stylistically diverse bands (including Bark Psychosis and Disco Inferno) whose only common denominator was the use of traditional rock instrumentation (guitar, bass, drums) in novel ways. These bands arose in the musical landscape of British indie rock, yet brought in diverse stylistic influences reaching back to German krautrock, The Velvet Underground, and Brian Eno. Since the early 1990s, however, what was once a very open-ended term has in many ways codified into a stable genre with its own fan community, dedicated festivals and a canon of central bands (which includes Godspeed You! Black Emperor, Mogwai and Sigur Rós). In his sociological analysis, Ryan Hibbett interprets post-rock as an aesthetic development providing indie culture with a new injection of cultural capital necessary for the maintenance of its social functions $(2005,65)$. According to Hibbett, 'post-rock assumes a loftiness associated with high art; through a complex of signifiers, it dissociates itself from the mundane and the trivial, securing instead a cultural value predicated on exoticism and grandeur' (ibid., 65). Sigur Rós' association with post-rock is an important touchstone for approaching their musical style, which is frequently interpreted as both 'exotic' and 'grand'.

To illuminate the stylistic features of Sigur Rós analytically, I will turn to the song 'Svefn-g-englar' as an example. ${ }^{10}$ The track is an illustrative case, as it was the first song by the band that reached a wider audience and sparked much of the defining metaphorical language in their reception. 'Svefn' was originally released on an EP of the same title (1999),

\footnotetext{
${ }^{10}$ A literal translation of the title would be 'Sleep Angels', which is an Icelandic idiom meaning sleepwalkers. However, on an early promotional CD-R, the band has listed the song in English as 'Sleep-s-talkers'.
} 
and quickly received attention as Single of the Week in the British music magazine New Musical Express, in preparation for its later appearance as the opening track on the band's breakthrough album Ágcetis Byrjun. 'Svefn' thus became the first internationally known track by the band, and contains the defining characteristics of its musical idiolect.

'Svefn' is an expansive and slow-moving composition, where all the different musical parameters, including the studio production, are engaged in the creation of musical space. The sheer duration of the track (10:04) is significantly longer than the norms of its parent style, yet long durations are a key feature of Sigur Rós' music. Many songs in their discography pass the 10-minute mark, while some (like 'Untitled \#7', at 13:00) go even further. ${ }^{11}$

The song opens with an ambient wash of noise, a low-frequency rumble muffled as if heard underwater. A sonar ping (pitched at E) reinforces the experience of submerged listening. A vocal sample, taken from a later section of the same track but treated with compression and played in reverse, leads us into the first statement of the short harmonic progression that continues to repeat throughout the entire track (excepting a short contrasting section at 6:07-6:23). This is played by Kjartan Sveinsson on an organ voicing of the Yamaha SK-20 synthesizer, underpinned by a step-wise descending figure on Georg Holm's bass guitar:

\section{<Insert example 1 here $>$}

The continuous repetitions of the descending figure unfold steadily at a slow $55 \mathrm{bpm}$. The use of slow tempos is another defining feature of Sigur Rós' music. An unhurried, slow-burning approach to music is as typical of the band as it is untypical of paradigmatic rock style. Sigur Rós' slow tempos reaches an apex on the track 'Untitled \#5' from the album () (2002), where a common $6 / 8$ groove is slowed down to $17 \mathrm{bpm}$, far below the beats per minute needed for a common listener to experience any tempo at all, making the music appear static and without pulse. On 'Svefn', drummer Ágúst Gunnarsson plays an unchanging 4/4-beat using brushes instead of sticks, which reduces the attack of the drums as well as cutting the higher frequencies, resulting in a muffled sound emphasizing the lower tones of the drum set.

The formal structure of 'Svefn' is an expanded verse-chorus form with lengthy intro and outro sections that frame three verses, whose melodic material could be grouped as $A B$, A, CC'. The verses alternate with a recurring chorus-like motif, yet with no change in voice

\footnotetext{
${ }^{11}$ The mean duration of tracks from the first four studio albums is seven minutes (Dibben 2009, 138).
} 
register, harmonic progression, groove or dynamics, there is little here that signals 'this is a chorus'. Instead of the usual intensification afforded the rock chorus (often created through a change in register, dynamics, and instrumental texture), 'Svefn' rolls steadily on as if nothing has happened, using stasis as a means of subverting the verse-chorus paradigm of normative rock style.

The song is more aligned with a formal type that Brad Osborn defines as 'terminally climactic forms', which are 'characterized by their balance between the expected memorable highpoint (the chorus) and the thematically independent terminal climax, the song's actual high point, which appears only once at the end of the song' $(2012,23)$. 'Svefn' does indeed feature a thematically independent climax, yet it is not placed at the end of the song. When the song passes the five-minute mark, the instrumental texture diminishes as both drums and bass go silent, creating a sense of suspension as Jónsi's vocals are left hanging in the air, unsupported, while he chants four repetitions of the chorus-motif, building momentum. Suddenly, at 6:07, new harmonic, melodic, and textural material is finally introduced in the song's only contrasting section. Yet the climax is just a short cadence, bringing us back to square one at 6:23. In Figure 1, the climax is easily visible in the waveform image of the track, where a noticeable dynamic shift occurs at 6:07. This is coupled with the introduction of a new timbre, the Hammond B3 organ, only featured for the short duration of the climactic section (abbreviated as CS in figure 1), before Sveinsson returns to the Yamaha SK-20 for the final verse and outro. The position of the climax, then, lines up almost perfectly with the golden ratio: at 6:07 of the track's total length of 10:04.

\section{$<$ Insert figure 2 here $>$}

The extended introduction section of the track (0.00 - 1:57) slowly builds textural density around the repeated harmonic progression in the synth organ and bass. Once the voice enters, the instrumental texture remains static throughout the track, the only variation being the somewhat just-audible addition of the xylophone during the chorus sections. As is visible in the waveform image, dynamic variations in loudness are also kept at a minimum. This makes the track unfold as a slowly churning wheel: the harmonic repetition and lack of variations (both dynamic and textural) make the song appear cyclical. But the non-eventfulness of the track is of course a decoy, making the eruption of the climactic section all the more powerful and immediate. 
'Svefn' contains no harmonic tension: except for the short climactic section, there are no cadential progressions and no use of the leading tone. The result is a sense of harmonic stasis, yet without the use of a pedal or drone, as we often find in other Sigur Rós songs. In 'Glósóli', the opening track of the Takk ... (2005) album, the bass guitar repeats a slow, diatonic pattern in G major for the entire stretch. Another example is 'Hafssól' from the album Hvarf-Heim (2007), where the bass lingers on the same note, becoming an unrelenting drone, for the entire duration of the track (9:47). It is this use of harmonic stasis, coupled with extensive repetition and long durations of gradual cumulative form, which invites Nicola Dibben $(2009,139)$ to make the comparison to minimalist composers such as Arvo Pärt and Henryk Górecki.

Minimalism often shows up in discussions surrounding the post-rock genre. The Canadian band Godspeed You! Black Emperor (with whom Sigur Rós toured in 2002) titled one of their compositions 'Górecki' (the song was later released as 'Moya', but continued to be introduced as 'Górecki' in concerts). Jonathan Bernard sees the influence of Arvo Pärt in Sigur Rós songs like 'Ándvari', stating how 'the sheer sonic resemblance as well as the impression of an emptying out, or slowly coming to a standstill, is very reminiscent of works such as Pärt's Tabula Rasa (1977)' (2013, 344). ${ }^{12}$ A concrete 'point of contact' between Arvo Pärt and Sigur Rós can be found in the live repertoire of the band during their 2001 world tour. Concerts would begin with Kjartan Sveinsson alone by the grand piano, playing the solo piano composition Für Alina (which Pärt wrote in 1976), as an introduction while the rest of the band assembled on stage.

\section{Musical Spaces}

Scattered throughout the reception of Sigur Rós are different metaphors of spatiality. Although the band members themselves are noticeably tired of interviewers asking about the supposed inspiration from the 'vast, open spaces of the Icelandic landscape', certain points of reference in their musical practice makes such metaphors intelligible beyond emphasizing the nationality of the band. As shown in 'Svefn-g-englar', Sigur Rós employ several musical strategies for the evocation of spaciousness, including harmonic stasis, long durations, and slow tempos. Additionally, the music opens up by not being rhythmically crowded: the bass

\footnotetext{
${ }^{12}$ Bernard is referring here to the work of the Icelandic string quartet Amiina, which is featured in the ending of the track. Amiina recorded and toured with Sigur Rós in the period 1999-2007, and the collaboration between the two groups was an important ingredient in creating the instrumental textures often compared to minimalist music.
} 
guitar and organ mainly use whole notes, and the bowed guitar avoids rhythmic patterns all together. The track is characterised by a deliberate uneventfulness, with long spaces inbetween gestures. Another factor is the vertical arrangement of the instrumental texture within the frequency spectrum. On 'Svefn', the bass and synth organ fill out the lower end of the spectrum, leaving a wide-open gap in the middle frequencies, making Jónsi’s falsetto voice appear lonesome in the high end. From a listener's perspective, such openness in the frequency spectrum certainly communicates a sense of space, or of absence (considering how much modern pop music goes to great effort to fill every part of the frequency spectrum). The 'gap' in the middle frequency range in 'Svefn-g-englar' belongs to the bowed guitar, which is free to float in and out, often leaving the arrangement for a few seconds before entering again, emphasizing the empty space in the mix.

A certain fascination with space is also apparent in Sigur Rós's studio production practice. After receiving a great deal of money for the first time following the success of Ágatis Byrjun, the band used their money to convert an old swimming pool into a rehearsal space and studio, named simply Sundlaugin (literally 'the swimming pool'). The next album, ( ) (2002), was the first to be recorded at Sundlaugin, and the band made good use of its natural reverb. The high ceilings of the pool (sixteen feet) allow for a very resonant space, in which the band placed microphones high up in the four corners of the room, aiming to capture its natural acoustics (Ethan Hayden 2014, 89). The band uses artificial reverb effects as well (on Jónsi's guitar and vocals), mixing the natural reverb of the Sundlaugin space with other, virtual spaces.

\section{Sounding Sigur Rós: Timbral Characteristics of the Bowed Electric Guitar}

References to the 'sound' of Sigur Rós are ubiquitous throughout the band's reception. The discourses that map exoticism onto musical style often coalesce on the timbral characteristics of the bowed electric guitar. Keeping this iconic instrumental timbre at the forefront of the analysis is therefore key to understanding how listeners and critics interpret the musical meanings of Sigur Rós. Furthermore, as David Blake argues, 'timbre is the primary musical parameter for comprehending strategies of differentiation omnipresent in indie music' (2012, 11). Focusing on timbre, then, allows us to connect musical characteristics with social politics.

Timbre has the quality of being instantly recognizable and effective, but at the same time it is somewhat invisible to analysis. In the introduction to her article 'The Paradox of Timbre', Cornelia Fales writes: 'we're not deaf to timbre: we hear it, we use it - no one has 
much trouble telling instruments apart - but we have no language to describe it. With no domain-specific adjectives, timbre must be described in metaphor or by analogy to other senses, and this is true in many, many languages of the world' $(2002,57)$. Fales' lamentation for the necessity of reverting to metaphor or analogy in the description of timbre is countered by Zachary Wallmark (2014). In Wallmark's view, it is not that timbres have to be described in metaphor because of a lack of adjective vocabulary; we talk about timbre in this way because timbre is inherently metaphorical in nature. Wallmark argues from an embodiedecological perspective that "metaphors for timbre are not arbitrary, squishy things, but rather reflect deep, embodied, and fundamentally transformative characteristics of sonic experience. [...] The coherence of meaning attendant to timbre descriptors, despite their apparent ambiguity, betokens certain consistent, shared patterns of underlying bodily experience' $(2014,126)$. Taking the view that metaphors used to describe timbre are not arbitrary, then, such metaphors may be a good starting point for studying the timbral qualities of Sigur Rós.

We need to keep in mind that metaphors are performative, they work 'both ways'. We now hear Sigur Rós as 'glacial', 'mournful', or like 'the tinkling and cracking of ice floes drifting across the water' (Harrington 2001) because of the prevalence of such metaphors throughout the band's reception. These descriptions act as 'program notes', offering listeners a specific interpretative window through which to hear the music. This is similar to the programmatic descriptions accompanying nineteenth century instrumental works such as Beethoven's 'Pastoral' symphony and Berlioz' 'Symphony Fantastique'. I propose that the 'program notes' of metaphorical language in the reception of Sigur Rós can be linked to the perception of the specific timbre of the bowed electric guitar.

Jónsi's use of the bowed guitar technique is central to the Sigur Rós 'sound'. As bassist Georg Holm explains in a TV interview on the HBO show Reverb, this all came about as an instance of 'art through accident'. ${ }^{13}$ The original drummer in the band, Águst Gúnnarsson (who quit the band shortly after the release of Ágatis Byrjun), gave Holm the Christmas gift of a cello bow to use on his bass. However, Holm soon decided that bowing his bass guitar did not sound particularly useful, so instead the bow ended up with Jónsi, who thought it sounded interesting when used instead on his guitar. Since then, Jónsi has developed an idiosyncratic technique of bowing the electric guitar, and the cello bow has played an integral role in his playing, alongside more traditional rock guitar techniques.

\footnotetext{
${ }^{13}$ The episode of Reverb featuring Sigur Rós originally aired on 17.10.2002. A short excerpt is available at http://www.sigur-ros.co.uk/media/dldvideo.php (accessed 18 June 2018).
} 
Bowing the guitar strings alters the overtone spectrum through harmonic distortion. Depending on the angle of the bow, the point and angle of contact across the strings, as well as the amount of pressure applied, different harmonic overtones are emphasised. As the stringboard on a guitar is flat (no bridge), controlling which strings are bowed simultaneously is difficult. When coupled with the fact that a resonating guitar string may alter its overtone structure as a result of extremely small changes in pressure of the bow, a chaotic element of randomness is introduced, pertaining to which harmonics of the string sound at a given moment. Jónsi puts it this way: 'With a bow you can get loads and loads of overtones so it's about how you handle them. It's like you're riding a really mad horse and you're trying to tame it' (Pytlik 2002)..$^{14}$

Bowing the guitar produces a sound that is significantly different in its acoustic properties compared to the sound that results from a picked or finger-strummed string. With regard to its envelope, a picked string on the electric guitar will produce a sound with a noticeable attack, followed by a long (possibly infinite) sustain. However, in normal playing situations, the sound will typically be cut with a short decay (either controlled by the fingers on the fretboard or with slight muting by the palm of the picking hand). By comparison, the sound resulting from a bowed string will yield no noticeable attack, rather making possible a fade-in. Because of a different positioning of the bowing hand, muting the string using the palm will be awkward. Jónsi uses the volume knobs on his guitar instead, allowing a more controlled and possibly much longer decay.

The technique of playing the guitar with a bow is not the only defining feature of Jónsi's guitar sound. Significantly, his guitar signal is treated with a high amount of reverb. This is what distinguishes Jónsi's guitar playing from other bowed guitar sounds like that of Jimmy Page on the Led Zeppelin song 'Dazed and Confused' or Lee Rinaldo's bowed guitar during the introduction to 'Hey Juni' by Sonic Youth. A more contemporaneous comparison would be Jonny Greenwood's bowed guitar during the live performances of Radiohead tracks such as 'Pyramid Song', where he will use reverb effects similar to Jónsi. The high amount of reverb means a chord will continue to sound after Jónsi has changed to the next harmony, thereby producing a clashing moment when the two chords sound together. In other words, Jónsi uses the long decay of the reverb to produce complex harmonic structures bordering on

\footnotetext{
${ }^{14}$ In the first years of touring with Sigur Rós, Jónsi used a normal Gibson Les Paul, but in 2004 his guitar technician constructed a customised model with a higher fingerboard and fingerboard/bridge/nut radius (the arc of the fingerboard across its width), thereby making this instrument tailored to the bowing technique ('Rig Rundown' 2016).
} 
noisy, microtonal clusters. At the entrance of the guitar at 1:22 in 'Svefn-g-englar', Jónsi continuously bows the lowest (E) string while sliding his finger along the entire neck of the guitar, utilizing the reverb to make all the possible harmonics of the E-string sound together. ${ }^{15}$ The resultant sound is a dense cluster, bordering on noise, as can be seen in the spectrographic visualisation below.

\section{$<$ Insert figure 3 here $>$}

The image shows the low to mid frequency range at 1:21.05-1.24.07 of 'Svefn-g-englar'. The guitar slide becomes a cluster that increasingly spreads out across frequencies and blurs distinctions between frequency bands, making for a particularly noisy spectrographic image. Near the end of the X-axis, acoustic energy (the red colour) is spread out across a wide frequency range. The fundamental frequency of the E-string is $82.41 \mathrm{hz}$.

The extended instrumental technique of bowing the guitar is a physical gesture that is unfamiliar and exotic to most listeners and audience members. This technique is used in combination with the rather small and slow movement of Jónsi's bowing arm to produce an intensely loud and even distorted sound. For observant audience members, the sound produced and visual effort might seem at odds: the physical movements and gestures of the musician do not match the sound it produces. The sound of the bowed guitar seems to bypass the rules of the physical-acoustic world we have come to known, where loud and distorted sounds are the product of great physical strain or exertion. This may shed light on why one reviewer for The New York Times called the sounds produced by Jónsi's guitar 'disembodied' (Pareles 2001). They are alien acoustic phenomena that exist strangely outside of our schemas for the perception of musical sound as emanating from gesturing bodies.

Keeping this in mind, the metaphors of otherness that crop up throughout the reception of Sigur Rós may have their basis as much in the musical style itself as in ideas of nationality and geography. Everything about Jónsi's guitar sound, from the way he moves and gestures with his instrument to the amount of reverb he applies, goes against any expectations the listener may bring to this music, based on normative rock style or previous familiarity with guitar technique. Jónsi's guitar sound differs fundamentally from dominant guitar style in rock music, both in its acoustic properties and its means of production.

\footnotetext{
${ }^{15}$ This specific movement can be seen at 2:24 in https://www.youtube.com/watch? $=\mathrm{vWR}-\mathrm{jJ} 3 \mathrm{vlpk}$ (accessed 18 June 2018).
} 
The view that indie rock culture makes up a social discourse of differentiation against the mainstream music industry is commonly held within popular music studies (Hesmondhalgh 1999; Hibbett 2005; Bannister 2006). David Blake (2012) argues that the parameter of timbre is key to understanding how such strategies of differentiation and independence are worked out in the music itself. Indeed, the search for unique timbres (by way of instrumentation, new instrumental techniques, or studio production) is perhaps the most unifying characteristic of post-2000 indie music in Iceland and elsewhere. With Sigur Rós, this differentiation happens most obviously at the level of the guitar. The electric guitar is perhaps the most effective signifier of traditional rock ideology, including conceptions of white masculinity. Indie music has aspired to subvert such ideological conceptions for decades, and Sigur Rós is no exception. In Jónsi's decision to pick up the bow we see a total abandon of the guitar as carrier of masculine power, and a search to redefine the gendered meanings of the instrument. Significant here is also Jónsi's performance posture: he is more or less always standing still, never engaging in any of the physical displays of male power associated with mainstream rock music, offering a different and more introverted rock identity. The bowed guitar becomes not only a strategy of timbral differentiation, but also an arena for representations of gender and identity. The social politics of Sigur Rós thus becomes apparent in the many ways that their music creates 'friction' in its dialogue with the dominant discourses of rock. The bowed guitar timbre is, however, not the only aspect of the band's practice that articulates such frictions. Also important in this respect is Sigur Rós' idiosyncratic use of voice and language.

\section{Vocal Idiom and Linguistic Features}

After 'Svefn-g-englar' progresses through a lengthy intro-section featuring the bowed guitar, the first entrance of the voice occurs at 1:57. The first verse consists of a slow-moving melody in countertenor register, sung by Jónsi in his trademark falsetto. Aside from the bowed guitar, Jónsi's vocal idiom is the most recognizable sonic marker of the band: his falsetto register extends up to at least B5. A high point occurs in 'Hoppípolla', which is in the bright key of B major, where Jónsi holds a long note on B5 at 2:35. Another B5 occurs at 3:34 in 'Gong' (key of F\# minor). An example of Jónsi using the low end of his chest range is 'All Alright', where the first verse is based on a pitch collection centred on D3.

Just as with the unusual technique of bowing his guitar, the fact that Jónsi became Sigur Rós' vocalist happened rather accidentally. He started to sing because 'there was no one else' to do the job, and his decision to use the falsetto technique came quite naturally to him: 
'I sang that way because I was shy ... I found that when I sang falsetto I could tune my voice more and control it' (Sandall 2005).

Jónsi's voice is frequently described using adjectives such as 'angelic', 'ethereal' or 'unearthly.' His fragile falsetto has been interpreted in terms of its androgynous qualities by Miller (2003), who describes it by reference to the uncanny nature of the boy soprano voice. In Miller's words, the falsetto is a vocal technique that 'extends a male's voice, moving beyond restraints, harking back to a boy's voice, and reaching forward to a woman's range, without ever sounding female' (ibid., unpaginated). Theorists at the intersection of queer theory and popular musicology, such as Stan Hawkins (2009) and Freya Jarman-Ivens (2011), view the voice as a particularly rich site for the emergence of queer. These scholars take a performative perspective on queer as the act of queering, something that draws attention to the constructedness of sexuality and its relationship with identity. From this perspective, Jónsi's vocal idiom operates - alongside his bowed guitar - as a way of problematizing the relation of musical sounds to gender categories.

To produce Jónsi's unique vocal expression, the queer potential of the falsetto vocal technique works together with the phonographic staging of the voice on the recording (Serge Lacasse 2010). On 'Svefn-g-englar', Jónsi's voice is treated with a reverb effect with a long decay, which acts to position the voice 'far away' in the virtual space of the recording. Overdubbing and multi-tracking of the voice are used so that Jónsi appears on the recording as his own backing-singer, with the backing-lines given different positions (using stereo panning) and different amounts of reverb, appearing much nearer on the near-far axis of the mix. Another key production aspect is the band's fondness of the reverse reverb effect. Reverse reverb is applied to short samples of vocal lines which are then placed at the beginning of melodic phrases, making Jónsi's voice appear to emerge organically from the decay of his own voice, certainly a rather eerie and 'unearthly' effect. In this way, the phonographic staging heightens the ambiguous and somewhat uncanny nature of the falsetto voice. This may account for descriptions of Jónsi's voice as 'ethereal' and 'surreal'. ${ }^{16}$

The term 'surreal' is common throughout Sigur Rós' reception and is in many cases related to the band's use of the Icelandic language, as well as the many songs that feature no language at all (simply using non-sensical vocalization). Viewed against the hegemony of English in contemporary popular music styles, Sigur Rós is an unprecedented case: they are

\footnotetext{
${ }^{16}$ In their analysis of Kate Bush's 'Get Out of My House', Ragnhild Brøvig-Hanssen and Anne Danielsen suggest how effects such as reverse reverb and gated reverb are experienced as surreal because they do not naturally occur in actual physical spaces $(2016,41)$.
} 
the only band in popular music history to achieve global success (selling out 5,000 seat arenas on all continents) without singing in English. ${ }^{17}$

The band continued to write their lyrics in a language spoken by approximately 400,000 people even as they achieved worldwide fame. As non-Icelandic speakers make up the biggest part of their audience, this carries important musical implications. When listeners are not able to understand the lyrics, attention is diverted to other features of the music, making listeners engage more with the non-semantic aspects of the voice, such as timbre and prosody, revealing the expressive and communicative possibilities of non-intelligible song. Sigur Rós is unique in its use of the Icelandic language, but the band is equally renowned for the moments when they are not using any language at all: 'Svefn-g-englar' features both Icelandic lyrics (on the verses) and non-semantic vocalization in the chorus sections. The use of non-semantic vocalization in many Sigur Rós songs has been studied in terms of its lineage to dada and surrealism (Emil Hjörvar Petersen 2008; Ethan Hayden 2014) as well as its nostalgic qualities and childlike playfulness (John Richardson 2012; Nadav Appel 2014). It is frequently misconstrued as an invented language, as the band gave it the name Vonlenska ('Hopelandic'), after the first recorded song ('Von', or 'Hope', 1997) featuring this type of vocalization. This arguably unique musico-lingual practice is one of the features of Sigur Rós' music that are often confounded with borealism to construct images of an 'ancient' or 'mysterious' Iceland.

\section{Conclusion}

Sigur Rós' anglophone reception clearly demonstrates the continued importance of nation and nationhood as an interpretative window through which listeners experience and make sense of music, well into this 'globalized age'. This is potentially problematic, all the while our notions of national difference rests on deep-set mythologies that maintain centre/periphery power structures. This is a complexity that artists and bands such as Sigur Rós have to negotiate in the ongoing fashioning of their artistic identities.

Remaining critical of efforts to 'explain' musical style by reference to ideas of nationhood is important also for the fields of musicology and music historiography more broadly (Weisethaunet 2007). For instance, recognizing Jónsi’s pioneering guitar technique as an act of artistic creativity, rather than focusing on 'a strong degree of Icelandic animism in

\footnotetext{
${ }^{17}$ The song 'All Alright', which appears as the final track on the album Með suð i eyrum við spilum endalaust ('With a Buzz in Our Ears We Play Endlessly', 2008), is quite exceptional in the Sigur Rós catalogue, simply because it is the only song so far with English lyrics.
} 
their music' (Tony Mitchell 2009, 191), would do much more justice to the actors involved. It would also be more precise: 'Icelandic animism' does not exist anywhere in the anthropological literature.

With this article I sought to dispel a few of the longstanding myths surrounding Sigur Rós. My aim was to pick apart interpretative strategies among listeners and critics, using the concept of borealism to contextualize the band's reception within a long history of exotic representations of the Nordic region. The analysis of 'Svefn-g-englar' nonetheless showed how certain tropes in the reception, such as those emphasising an experience of spaciousness and the 'unearthly', might be related to specific musical-stylistic details, including Jónsi's falsetto vocal idiom and the band's timbral experimentation with the bowed electric guitar. This article was admittedly narrow in scope, focusing on one particular period of the band's multifarious career, and one delineated part of their reception (UK and US music journalism). How would the situation look, for instance, in Japan, where Sigur Rós has achieved huge success? How is musical borealism articulated in other places and in other media spaces? These are potential areas of future inquiry. We are now seeing a surge in the international popularity of Nordic music, which requires more critical research on the intersections of representation, reception, and agency (see Fabian Holt 2017). As this article has hopefully demonstrated, a musicological perspective that keeps issues of musical style and aesthetics in view can reveal how these processes are mapped unto musical sounds. 


\section{Bibliography}

Appel, Nadav. 2014. 'Ga, Ga, Ooh-La-La': The Childlike Use of Language in Pop-Rock Music.' Popular Music 33 (January): 91-108.

Bannister, Matthew. 2006. 'Loaded': Indie Guitar Rock, Canonism, White Masculinities.' Popular Music 25 (01): 77-95.

Bernard, Jonathan. 2013. 'Minimalism and Pop: Influence, Reaction, Consequences.' In The Ashgate Research Companion to Minimalist and Postminimalist Music, edited by Keith Potter, Kyle Gann, and Pwyll Ap Siôn, 337-55. Farnham: Ashgate.

Bohlman, Philip V. 2017. "Musical Borealism: Nordic Music and European History." In The Oxford Handbook of Popular Music in the Nordic Countries, edited by Fabian Holt and Antti-Ville Kärjä. Oxford: Oxford University Press.

Brøvig-Hanssen, Ragnhild, and Anne Danielsen. 2016. Digital Signatures. Cambridge, Mass: MIT Press.

Cannady, Kimberly D. 2014. History on Their Shoulders: Music and Nation-Building in Iceland. Ph.D. diss., University of Washington.

Cannady, Kimberly. 2017. "Echoes of the Colonial Past in Discourse on North Atlantic Popular Music." In The Oxford Handbook of Popular Music in the Nordic Countries, edited by Fabian Holt and Antti-Ville Kärjä, 203-17. Oxford: Oxford University Press.

Crysell, Andy. 2000. 'Sigur Ros: Iceland's Magical Visionaries.' New Musical Express. http://www.rocksbackpages.com/Library/Article/sigur-ros-icelands-magical-visionaries (accessed September 13, 2016).

Dibben, Nicola. 2009. 'Nature and Nation: National Identity and Environmentalism in Icelandic Popular Music Video and Music Documentary.' Ethnomusicology Forum 18 (1): 131-51.

DiCrescenzo, Brent. 1999. 'Agaetis Byrjun.’ Pitchfork. June 1. http://pitchfork.com/reviews/albums/7151-agaetis-byrjun/ (accessed October 20, 2016).

Emmerson, Simon. 1999. “Aural Landscape: Musical Space.” Organised Sound 3 (2): 13540.

Fales, Cornelia. 2002. 'The Paradox of Timbre.' Ethnomusicology 46 (1): 56-95.

Fletcher, Lawson. 2011. “The Sound of Ruins : Sigur Rós' Heima and the Post-Rock Elegy for Place.” Interference Journal, no. 2: 1-11. http://www.interferencejournal.com/articles/a-sonic-geography/the-sound-of-ruins. 
Fricke, David. 1988. 'The Sugarcubes: The Coolest Band in the World.' Rolling Stone. July 14. http://www.rollingstone.com/music/features/the-coolest-band-in-the-world19880714 (accessed September 12, 2015).

Gillis, John R. 2004. Islands of the Mind. How the Human Imagination Created the Atlantic World. New York: Palgrave Macmillan.

Hall, Thorbjörg D. 2014. 'Nostalgic Qualities in the Film Heima by the Icelandic 'Krútt' Band Sigur Rós.” Social Alternatives 33 (1): 39-43.

Harrington, Richard. 2001. 'Sigur Ros's Gloriously Glacial Music.' The Washington Post. September 21. https://www.washingtonpost.com/archive/lifestyle/2001/09/21/sigurross- gloriously-glacial-music/41327ee5-5b4d-4c34-aad8-2f7af4a1346d/ (accessed January 24, 2016).

Hawkins, Stan. 2009. The British Pop Dandy: Masculinity, Popular Music and Culture. Farnham: Ashgate.

Hayden, Ethan. 2014. (). New York: Bloomsbury.

Hesmondhalgh, D. 1999. 'Indie: The Institutional Politics and Aesthetics of a Popular Music Genre.' Cultural Sociology 13 (1): 34-61.

Hibbett, Ryan. 2005. 'What Is Indie Rock?' Popular Music and Society 28 (1): 55-77. Hjálmarsson, Gunnar Lárus. 2013. Blue Eyed Pop. The History of Popular Music in Iceland. Reykjavík: Dr. Gunni.

Hodgkinson, James A. 2004. 'The Fanzine Discourse over Post-Rock.' In Music Scenes: Local, Translocal, and Virtual, edited by Andy Bennett and Richard Peterson. Nashville: Vanderbilt University Press.

Holt, Fabian. 2017. "Introduction. Music in a Globalizing Region.” In The Oxford Handbook of Popular Music in the Nordic Countries, edited by Fabian Holt and Antti-Ville Kärjä. Oxford: Oxford University Press.

Hyltén-Cavallius, Sverker, and Lars Kaijser. 2017. "Swedish Prog Rock and the Search for a Timeless Utopia." In The Oxford Handbook of Popular Music in the Nordic Countries, edited by Fabian Holt and Antti-Ville Kärjä, 219-36. Oxford: Oxford University Press. Ísleifsson, Sumarliði and Daniel Chartier (eds.). 2011. Iceland and Images of the North. Québec: Presses de l’Université du Québec.

Jarman-Ivens, Freya. 2011. Queer Voices - Vocalities, Technologies, and the Musical Flaw. New York: Palgrave Macmillan. 
Karlsdóttir, Unnur B. 2013. "Nature Worth Seeing! The Tourist Gaze as a Factor in Shaping Views on Nature in Iceland." Tourist Studies 13 (2): 139-55.

Klein, Joshua. 2002. 'Iceland's Sigur Ros Serious about Its Otherworldly Sound.' The

Chicago Tribune. November 12. http://articles.chicagotribune.com/2002-11-

12/features/0211110283_1_orri-pall-dyrason-band-glacier (accessed December 03, 2015).

Lacasse, Serge. 2010. "The Phonographic Voice: Paralinguistic Features and Phonographic Staging in Popular Music Singing." In Recorded Music: Performance, Culture and Technology, edited by Amanda Bayley. Cambridge: Cambridge University Press.

Mclean, Craig. 2006. "Mordor on the Dancefloor." The Word, October: 64-67.

Miller, Edward. 2003. 'The Nonsensical Truth of the Falsetto Voice: Listening to Sigur Rós.' Popular Musicology Online. http://www.popular-musicologyonline.com/issues/02/miller.html.

Mitchell, Tony. 2009. "Sigur Rós’s Heima: An Icelandic Psychogeography.” Transforming Cultures EJournal 4 (1).

Moore, Allan F. 2012. Song Means: Analysing and Interpreting Recorded Popular Song. Farnham: Ashgate.

Osborn, Brad. 2012. 'Subverting the Verse-Chorus Paradigm: Terminally Climactic Forms in Recent Rock Music.' Music Theory Spectrum 35 (1): 23-47.

Oslund, Karen. 2011. Iceland Imagined. Seattle: University of Washington Press.

Pareles, Jon. 2001. 'Icelandic Alchemists Turn Elementary Into Elemental.' The New York Times, May 12. http://www.nytimes.com/2001/05/12/arts/rock-review- icelandicalchemists-turn-elementary-into-elemental.html (accessed September 03, 2015).

Petersen, Emil Hjörvar. 2008. "Vonlenskan Sem Framúrstefna.” Tímarit Máls Og Menningur, no. 1: 5-17.

Petrusich, Amanda. 2008. "Sigur Rós.” Pitchfork, October 13. https://pitchfork.com/features/interview/7536-sigur-ros/ (accessed May 05, 2018).

Pitchfork. 2009. 'The Top 200 Albums of the 2000s: 20-1.' Pitchfork. October 2. http://pitchfork.com/features/staff-lists/7710-the-top-200-albums-of-the-2000s- 20-1/2/ (accessed February 02, 2016).

Prior, N. 2014. “'It's A Social Thing, Not a Nature Thing': Popular Music Practices in Reykjavik, Iceland.' Cultural Sociology 9 (1): 81-98. 
Pytlik, Mark. 2002. 'Ken Thomas \& Jonsi Birgisson: Recording Sigur Ros.' Sound on Sound. July. http://www.soundonsound.com/sos/jul02/articles/sigurros.asp (accessed January $05,2016)$.

Richardson, John. 2012. An Eye for Music: Popular Music and the Audiovisual Surreal. An Eye for Music: Popular Music and the Audiovisual Surreal. Oxford: Oxford University Press.

'Rig Rundown - Sigur Rós’ Jón ‘Jónsi’ Pór Birgisson, Georg ‘Goggi’ Hólm \& Kjartan Dagur Hólm.’ 2013. Premier Guitar. May 21.

https://www.youtube.com/watch?v=xbgnG2mAWWw (accessed January 19, 2016).

Said, Edward. 1979. Orientalism. New York: Vintage.

Sandall, Robert. 2005. 'The Icemen Cometh.' The Sunday Times, August 28. http://www.thesundaytimes.co.uk/sto/culture/music/article145793.ece (accessed January 21, 2016).

Schram, Kristinn. 2011. Borealism. Folkloristic Perspectives on Transnational Performances and the Exoticism of the North. Phd diss. The University of Edinburgh.

Thorodssen, Árnar Eggert. 2005. “Allir Sem Einn.” Morgunblaðið, June 19. https:/www.mbl.is/greinasafn/grein/1023785/?item_num=2\&searchid=f3996158dcd6fc 3cf92792201e01b5fd1c3bee1c (accessed May 05, 2018).

Wallmark, Zachary Thomas. 2014. Appraising Timbre: Embodiment and Affect at the Threshold of Music and Noise. Ph.D diss., University of California.

Weisethaunet, Hans. 2007. "Historiography and Complexities: Why Is Music 'National'?" Popular Music History 2 (2): 169-99.

Weisethaunet, Hans, and Ulf Lindberg. 2010. “Authenticity Revisited: The Rock Critic and the Changing Real." Popular Music and Society 33 (June 2013): 465-85.

Whitaker, Ian. 1982. 'The Problem of Pytheas' Thule.' The Classical Journal 77 (2): 148- 64. 


\section{Discography:}

Sigur Rós. 1997. Von. Smekkleysa SM67, compact disc.

Sigur Rós. 1999. Ágatis Byrjun. Smekkleysa SM79, compact disc.

Sigur Rós. 2002. (). FatCat Records FATCD22, compact disc.

Sigur Rós. 2005. Takk. . EMI 337252 2, 009463372522 5, compact disc.

Sigur Rós. 2007. Hvarf-Heim. EMI 5099950256624, 5025662, compact disc.

Sigur Rós. 2008. Með Suð i Eyrum Við Spilum Endalaust. EMI 228 7282, compact disc.

\section{Videography:}

Glósóli ('Glowing Sole'), Sigur Rós. Dir. Arni Kinski, 2005

Svefn-g-Englar ('Sleepwalkers'), Sigur Rós. Dir. August Jakobsson, 2000.

Sceglópur ('Lost Seafarer'), Sigur Rós. Dir. Sigur Rós and Eva Maria Daniels, 2006. 